\title{
'We ... galloped hard and straight over some big stone gaps': Freedom of the Hunt for Elite Women in Ireland, 1860-1914
}

\author{
Maeve O'Riordan \\ School of History, University College Cork \\ Ireland
}

(c) Maeve O'Riordan. This work is licensed under the Creative Commons Attribution-

NonCommercial-NoDerivatives 4.0 International License. To view a copy of this license, visit

http://creativecommons.org/licenses/by-nc-nd/4.0/.

\begin{abstract}
Hunting was an elite social pastime accessible to both men and women, of the correct social class, throughout the period 1860-1914. Female involvement in this sport preceded their widespread involvement in other sports and pastimes such as tennis and cycling. This article explores the contradictions inherent in women's involvement in this masculine sport. The sport demanded that participants display contemporary masculine characteristics of bravery, strength, and independence, and yet it was open to both married and unmarried women of the gentry and ascendancy class in Ireland. The sport was a dangerous one, and considerable skill was demanded of all participants. However, daughters of hunting families were not persuaded against joining the hunt, and were instead encouraged to display the necessary skill and competitiveness to ride a horse side-saddle cross-country at speed; jumping stone walls and banks along the way. It was the norm for women to wear adapted dress modelled on masculine hunting attire, however this dress did not diminish their perceived femininity, and was perceived by some in hunting circles as the most alluring form of female dress.
\end{abstract}

The article explores the numbers of women involved in the sport during the period utilising both contemporary fiction and directories. It also provides a case study of one woman's experience as she partook of the hunt while also battling long term ill health; challenging the contemporary notion of women as inherently weak and unable for rigorous physical activity.

Keywords: Women; Sport; The hunt; Nineteenth century; Irish ascendancy; Gentry Dress; Women; Gender; Health

Esther Grehan and her husband, a Catholic landlord, arrived late to the hunt at Cahirmee in North Cork in February 1894. They made up ground by galloping their horses hard over the countryside. Grehan was one of many wealthy women who, during the last decades of the nineteenth century, enjoyed the liberation associated with pushing her body to its limits while she guided her horse at speed across the Irish countryside. Hunting became more formalised as a sport over the course of the nineteenth century, and during this time, female participants could be seen in ever-increasing numbers. Women's participation in hunting in Ireland was one of the more contradictory practices of the nineteenth century. Excelling at the sport required attributes perceived to be masculine, yet it was one of the first sports to permit, and even welcome, female involvement. A small minority of women gained access to leadership 
positions in the sport of hunting in advance of other developments in women's rights sought by feminist activists of the day. It was a sport which required women to wear altered dress modelled on masculine attire. This dress was not perceived as subversive; its purpose was to show off the female form at its most alluring to the heterosexual male gaze. Foxhunting was a sport which could be physically challenging, yet involvement was possible for both men and women who were often deemed too young, too old or too infirm to participate actively in other sports. It was a sport which allowed considerable physical freedom and independence to participants at a time when socially-elite women, and particularly young unmarried women, might be presumed to live very circumscribed lives. The freedom of the hunting community was somewhat limited during the last decades of the nineteenth century as the hunt became a site of class warfare during the Land War. ${ }^{1}$ This period also saw an increased democratisation of membership as the rising middle classes bought their way into the hunting fraternity, at the same time as women were becoming more involved in the field. These contradictions only serve to highlight the need to explore female experiences in sport: not just the experiences of those who achieved limited celebrity status, but the experiences of women who engaged with sport, as Paul Rouse has written, 'for the joy of play'. ${ }^{2}$ This article will explore the experiences of some women who embraced the hunt, despite these contradictions, in an Irish context. The article focuses especially on the physical freedom enjoyed by women who were not celebrity sportswomen. First, it is necessary to examine the sport in the context of the culture of the day.

\section{Hunting and nineteenth-century society}

Hunting was an expression of multiple layers of identity, whether women were actively trying to expand the permitted activities and social boundaries of their sex, or were more focused on expressing elite-class solidarity. These women rode a narrow line between the masculine nature of their interest and the importance of preserving their perceived femininity. This line could only be safely and successfully pursued by women who had the protection of class status and family support. Female involvement in sport has always been tied up with notions of propriety and femininity. The leading researcher on women as sportspeople in Ireland, Katie Liston, has explored these concepts more fully in the closing article of this collection. ${ }^{3}$ The clash between sporting involvement and perceived femininity was presented in sharp relief during the second half of the nineteenth century. Increased female participation in sport in Ireland occurred against a backdrop of a traditional patriarchal society faced with campaigns for increased women's rights across the entire social spectrum: from voting rights, to access to education on the same terms as men, to increased bodily autonomy with the campaign against the Contagious Diseases Acts as well as the actions of women who managed to gain access to new fields of employment. Some perceived the public space as being invaded by 'New Women' who had disposable income and a thirst for greater political freedom; women who were not afraid to dress their bodies in more androgynous styles, and who were eager to push their sporting bodies to new physical limits during their leisure hours. When we examine women's actions in the field of sport, Amanda Vickery's statement on the notion of separate spheres becomes relevant. Observing an explosion during the early nineteenth-century in didactic literature on the importance of women remaining in the home, Vickery argued that we should not read this as evidence that the female sphere was becoming smaller and more controlled, but as evidence of

\footnotetext{
${ }^{1}$ L.P. Curtis, Jr., 'Stopping the Hunt, 1881-1882: an Aspect of the Irish Land War' in Nationalism and Popular Protest in Ireland ed. C.H.E. Philpin ([1987] Cambridge, 2002), 349-402. 354.

2 Paul Rouse, 'The sporting world and the human heart: Ireland, 1880-1930', Irish Studies Review 27, no. 3 (2019): 309-324. 311.

${ }^{3}$ See Katie Liston, 'Honour and Shame in Women's Sport', in this issue.
} 
the fear of women claiming more and more freedom within the public sphere. ${ }^{4}$ Newspaper editors received countless letters discussing the appropriateness (or otherwise) of women being physically activity and expressing their competitiveness in the decades after 1860. I have discussed these more fully in a forthcoming chapter on women and sport during the period 1850-1914, in the Atlas on Sport in Ireland. Despite the criticism levelled at women who were deemed to either unsex themselves, or to overly feminise a sport by their participation, women started to play sports as diverse as cricket and camogie, archery and swimming in everincreasing numbers during the last three decades of the nineteenth century, in particular.

\section{Hunting dress}

Hunting was a performance for everyone involved, and dress and appearance were taken very seriously. Women were committed to wearing the correct attire. In January 1895, Grehan rubbed her skin off on the saddle and borrowed her husband's drawers to wear under her clothes in order to be able to ride comfortably, but there was never a suggestion of riding a horse astride or wearing something other than a riding habit. ${ }^{5}$ Women's hunting attire was the most masculine of approved clothing available to upper-class women in the 1860 s. $^{6}$ Daughters of landlords attended tailoring companies to have made-to-measure beaver-fur hats, stiff collars and tail-coats tailored to match those of their brothers. Female members of the Galway Blazers Hunt Club, for example, wore white collars on their hunting jackets. ${ }^{7}$ Just as boys were 'breeched' and moved out of the feminine sphere of the home as they grew older and as an expression of their burgeoning masculinity, girls were prevented from riding astride to emphasise their femininity. Girls and women were fitted with a riding habit, which involved a skirt which stretched extra-long on one side, to ensure that no piece of their leg might show as they were riding. Ideally, each rider also had a custom-made saddle, which was designed for their own body and horse size, though not everyone could afford this. The masculine/feminine hybrid of the top hat, shirt, waistcoat, cravat and jacket, with the long skirt in woollen fabric was perceived by many as deeply alluring. Daisy Fingall, Countess of Fingal, was fearful of hunting, but she still fondly remembered how she looked in her riding habit which 'gave away' and 'showed off' her figure, and her shiny hat with its 'becoming...little curly brim' several decades later. ${ }^{8}$ Likewise, Mary, Lady Carbery, who professed to being turned off hunting when she saw a fox being killed, but continued to ride daily, had a vivid sense of her sexual allure as a teenager on her first hunt, riding her horse, Flirt. ${ }^{9}$ Esther Grehan too admired her two eldest daughters May (11) and Magda (10), who were dressed in new riding habits and arrayed with buttonholes to participate in their first meet. ${ }^{10}$ There was honour to be maintained but also to be accrued, in the ways in which these women, as social elites, represented their families and themselves.

Hunting women were not subjected to the same ridicule as that of women who donned divided skirts to ride bicycles. ${ }^{11}$ The reason for this might be traced to the class background of

\footnotetext{
${ }^{4}$ Amanda Vickery, 'Golden Age to Separate Spheres? A review of the categories and chronology of English women's history', Historical Journal 36, no. 2 (1993): 383-414.

${ }^{5}$ Esther Grehan, diary entry, 28 January 1895; 2 February 1895.

${ }^{6}$ Erica Munkwitz, 'Angels and Amazons: Fox-hunting and Sporting Emancipation for Women', The International Journal of the History of Sport 35, no. 6 (2018): 511-529.

${ }^{7}$ British Hunts and Huntsmen [four vols.] (London: Biographical Press, 1909-11).

${ }^{8}$ Paula Hinkson, Seventy Years Young: Memories of Elizabeth, Countess of Fingall (Dublin: Lilliput Press, 1992), 93-4.

${ }^{9}$ Mary Carbery, Happy World: Story of a Victorian Childhood (Longmans, Green: 1941), 194.

${ }^{10}$ Esther Grehan, diary entry, 30 November 1895.

${ }^{11}$ Katrina Jungnickel, "“One needs to be very brave to stand all that": Cycling, rational dress and the struggle for citizenship in late nineteenth-century Britain', Geoforum 64 (2015): 362-371.
} 
the women involved, and the extent to which they were perceived to uphold, rather than challenge, the class-based social system which had been in place for centuries. Hunting was, and always had been, a sport reserved for the rich. In these clothes, and on the back of a horse, albeit riding side-saddle, a woman had the freedom to ride across the country, jumping over ditches and stone walls, potentially damaging property, and witnessing the violent death of a worn-out fox at the teeth of a pack of hounds. On horseback, a skilled rider could be admired for her bravery and skill despite her gender. The sport of hunting allowed women, within certain circles, to embrace characteristics which were deemed to be the epitome of masculinity. In embracing the hunt, women were permitted to demonstrate strength, stamina, a 'strong stomach' for gore, bravery in the face of real physical danger, competitiveness, and the masculine art of horsemanship in a socially sanctioned way.

\section{Historiography of the hunt}

The history of women's sport in nineteenth-century Ireland is a history yet to be fully told. Despite some invaluable case-studies and surveys, there has yet to be a broad study of women and sport during this period which places female involvement in sport in the context of firstwave feminism (although Ó hÓgartaigh completed important work which placed sport in the context of other new areas for women such as medicine and education up to the $1960 \mathrm{~s}^{12}$ ). It would be extremely valuable to map sporting participants onto the membership of suffrage organisations, for example. ${ }^{13}$ This would go some way towards adding empirical flesh to the bones of the argument made by Liston in this issue, concerning the development of women's sports separate from other suffrage and equality movements. It cannot yet be argued with certainty whether sporting involvement might be taken on as a consciously feminist act, whether people played purely for the love of sport, were more concerned with the potential health benefits of an active life or a mix of these. There is some evidence that women might perceive of sporting activity as another branch of their quest for greater independence, but other active participants were actively anti-suffrage and politically conservative. Edith Somerville, who was the first female Master of Hounds in Ireland, was also president of the Munster Women's Franchise League, a relatively conservative suffrage organisation. ${ }^{14}$ Lady Castletown, who was an active member of the Duhallow Hunt, corresponded with the leading suffrage activist Anna Haslam about the idea of standing for election when it became legal for women to act as Poor Law Guardians. It cannot be known whether Castletown's contemplation of running for election reflected her feminist views or her self-perception as a landlord, and therefore a natural leader of her community despite her sex. ${ }^{15}$

Women's sporting activity during the nineteenth century has been valuably explored by leisure and sporting historians, though some sports have received greater attention than others. Brian Griffin has completed important work on both archery and cycling, and has explored how some sports might be perceived as more suitable for women than others (the stance required for archery was thought to expose the female form in the most attractive way). ${ }^{16}$ Tom Hunt has also carried out meticulous research on the sporting activity of men and women

\footnotetext{
${ }^{12}$ Margaret Ó hÓgartaigh, Quiet revolutionaries: Irish women in education, medicine and sport, 1860-1964 (London: The History Press, 2011).

${ }^{13}$ Something this article might have attempted on a case-study basis, had it not been written during the COVID19 pandemic with limited access to relevant archives.

${ }^{14}$ Gifford Lewis, Edith Somerville: a Biography (Dublin: Four Courts Press, 2005): 253. Somerville noted that all the work was really carried out by Suzanne Day.

15 Anna Haslam to Lady Castletown, 15 June 1896, NLI/MS/34, 166-67.

${ }^{16}$ Brian Griffin, 'The Big House at Play: Archery as an Elite Pursuit from the 1830s to the 1870s' in Irish Elites in the Nineteenth Century ed. Ciaran O'Neill (Dublin: Four Courts, 2013).
} 
in the county of Westmeath during the period, and has focused in particular on the female experience. ${ }^{17}$ This work, and careful mapping of female involvement in individual sports still needs to be carried out on a wider scale across the country. No doubt the forthcoming Atlas of Sport in Ireland will play an important part in mapping female sporting involvement across various codes. If we look at the sport of hunting in particular, the writer and artist Edith Somerville has received much attention. Her biographer Gifford Lewis identified the importance of horses and hunting in her life, while Laura Servilan Brown has explored Somerville's hunting activity, arguing that she was not driven by feminism in her participation. ${ }^{18}$ Drucker, using a colonial lens, has completed a case-study of the Grehan family's hunting practice in North Cork, demonstrating the extent to which hunting might be a statement of class position. ${ }^{19}$

Women's historical participation in sport has received attention from both historians and sociologists. Liston has valuably illustrated how some of the work within sociology can be disjointed as authors begin from functional, Marxist, feminist, or other starting points. ${ }^{20}$ The same silo-effect can be noted within the discipline of history: sports historians and gender historians need to engage more fully with each other's work, if we are to gain a rounded understanding of women (and men's) involvement in sport. It is essential to fully bridge this gap if women's sporting activity is to be fully explored in the context of their society at the time. Looking at Britain, there has been some historical work which spans gender history and sporting history. Within the sport of hunting, important research has been completed by Erica Munkwitz, who has a forthcoming book on the history of the side-saddle. ${ }^{21}$ Her recent work on sporting emancipation through hunting is an important analysis of this sport, which has not received the same level of attention in Britain as say cycling, which was a sport closely associated with the New Woman. ${ }^{22}$ Munkwitz has identified a similar phenomenon to that which has been found in Ireland: women could participate in the hunt, and be recognised as skilled huntswomen, despite the masculine nature of the sport, and without necessarily losing their femininity or respectability.

\section{History of hunting}

Hunting was traditionally the preserve of the aristocracy and landed gentry. Aristocrats had defined the parameters of the sport over centuries of participation with the modern format in existence since the fourteenth century. ${ }^{23}$ Hunting was an extremely expensive sport, which required the upkeep of packs of hounds, a rotation of hunting horses, the employment of staff as well as compensation to farmers whose lands or stock were damaged by the hunt. ${ }^{24}$ The primary barrier to taking part in the hunt, therefore, was class rather than gender. The Irish

\footnotetext{
17 Tom Hunt, Sport and Society in Victorian Ireland: the Case of Westmeath (Cork, 2007); Tom Hunt, 'Women and Sport in Victorian Westmeath', Irish Economic and Social History 34 (2007): 29-46.

${ }^{18}$ Lewis, Edith Somerville; L. Servilan Brown, 'Edith Somerville and the West Carbery Hunt, 1903-19' in Sport and Leisure in the Irish and British Country House ed. Terence Dooley and Christopher Ridgway (Dublin: Four Courts, 2019).

${ }^{19}$ Nicola Drucker, 'Hunting and Shooting_Leisure, Social Networking and Social Complications: Microhistorical Perspectives on Colonial Structures and Individual Practices - the Grehan family, ClonmeenHouse, Ireland' in Was Ireland a Colony? Economy, Politics, Ideology and Culture in NineteenthCentury Ireland ed. T. McDonough (Dublin: Irish Academic Press, 2005): 117-44.

${ }^{20}$ Katie Liston, 'Sport and Leisure', The Sociological Review 59: 160-180.

${ }^{21}$ Erica Munckwitz, Women, Horse Sports and Liberation: Equestrianism and Britain from the 18th to the 20th Centuries (Routledge, 2021 [forthcoming]).

${ }^{22}$ Erica Munkwitz, 'Angels and Amazons'; K. Jungnickel, “'One needs [...]”".

${ }^{23}$ Hunt, Sport and Society, 11.

24 Terence Dooley, Decline of the Big House in Ireland: a Study of Irish Landed Families, 1860-1960 (Dublin: Wolfhound Press, 2001), 57.
} 
landed elite, particularly in more fertile and low-lying areas of the country, such as counties Kildare and Meath, were long devoted to the hunt. Fox hunting was the most popular form of hunting in Ireland, but there were also hunts devoted to stag hunting. When Queen Victoria visited Ireland in 1861, she was invited to observe a stag hunt from the safety of a boat on Killarney lake. ${ }^{25}$ The historian of the Irish Ascendancy, Mark Bence-Jones has written that for the gentry, 'tennis, bicycling and fancy dress balls were, of course, very much subordinate to hunting'. ${ }^{26}$ The fox hunt in Ireland was developed 'on a grand scale' during the golden age of the landlord class from the 1790 s to the 1820 s as landlords established regional hunts. ${ }^{27}$ In postfamine Ireland, subscription hunts, rather than a private hunt funded by a single individual, became the norm. ${ }^{28}$ Depending on the size of the subscription fund, the capacity of the countryside, and the eagerness of the field, a hunt might go out up to four days per week during the winter, though twice weekly meetings were normal. ${ }^{29}$ The active participants of the hunt in Westmeath were comprised primarily of 'members of the local aristocracy and gentry, supplemented by officers from the Mullingar and Athlone military barracks and a number of women devotees of the sport'. ${ }^{30}$ By the 1905-06 hunting season, 'women made up one third of the hunting field'. ${ }^{31}$ The sport involved a pack of hounds (interchanging male and female packs on different days) chasing a wild fox over the countryside while being pursued by men and women on horseback at a speed of up to fifty kilometres per hour as they jumped over or avoided obstacles. The female riders in this period rode side-saddle, demanding additional balancing skills to stay on board. ${ }^{32}$ A day's hunting could be an exhausting test of stamina. Lord Naas, for example, recorded a particular hunt which took place in county Kildare in November 1859 as 'not only was it the best run ever known in Kildare, but the finest of any time in any country'. Only fifteen of the original 150 riders managed to keep up, and to be in at the kill after a twelve-mile chase. ${ }^{33}$ Towards the end of the nineteenth century the hunt field became more diversified with the addition of large farmers, shopkeepers, professionals and others who could afford to buy their way into the sport. ${ }^{34}$ Terence Dooley has observed that people of all classes might enjoy watching the hunt from on high as a form of entertainment. ${ }^{35}$

\section{Female participation}

Women's participation in hunting, as with many sports, relied to a large degree on the support of their male relatives. A small minority of elite women had always hunted. Queen Elizabeth I was recorded deer hunting, and Empress Elisabeth of Austro-Hungary famously continued the European royal tradition by taking hunting holidays in Ireland in the $1880 \mathrm{~s} .{ }^{36}$ She was nearly universally admired for both her feminine beauty and her masculine bravery and speed on horseback. ${ }^{37}$ A minority of non-royal elite women also hunted before the beginning of this

\footnotetext{
${ }^{25}$ Kerry Evening Post, 31 August 1861. Referenced by Muckross Research Library, http://www.muckrosshouseresearchlibrary.ie/Queen-Victoria.php.

${ }^{26}$ Mark Bence-Jones, Twilight of the Ascendancy (London: Constable, 1987): 63.

${ }^{27}$ Dooley, Decline, 57.

${ }^{28}$ Hunt, Sport and Society, 11.

${ }^{29}$ Ibid., 13.

${ }^{30}$ Ibid., 14.

31 Ibid., 18.

${ }^{32}$ Munckwitz, 'Angels and Amazons', 511.

${ }^{33}$ Dooley, Decline, 59.

34 Ibid., 57.

35 Ibid., 58.

36 Tony Canavan, "“Erin cordially welcomes the Empress”: Elizabeth of Austria-Hungary in Ireland, 1879 and 1880', History Ireland 19, no. 3 (2011): 30-33.

37 Ibid.
} 
period. ${ }^{38}$ Family, as well as background, were essential in facilitating a woman's interest in hunting. In an earlier study of twelve landed families in Munster, I found that no woman hunted who did not have the support of a significant male relative who also hunted. This was due, in part no doubt, to the fact that women had less access to the finance necessary to support a hunting habit. While women formed a part of the hunting field, they were not completely equal and the same responsibilities were not demanded of them as of their brothers. In the first decades of widespread female involvement, membership fees were not levied on female members of the hunt. When the Kildare Hunt considered levying a charge on female riders, one of the most aristocratic, Lady Castletown, objected vehemently. ${ }^{39}$

The importance of family connections can be seen in the (gendered) British Hunts and Huntsmen four-volume publication which was published on a subscription bases and sought to list all of the hunts and their primary members across Britain and Ireland, on a self-selection basis. The publication presented an introduction and brief history to each hunt before providing individual biographies of leading members. While women were involved in most hunts, they did not feature strongly in the hunt histories, suggesting that the compilers still viewed the hunt as a primarily masculine pursuit which could be enjoyed by female relatives, rather than as a purely egalitarian sport. The histories were typically male orientated; listing the Master of Hounds, what they did to protect coverts and breed hounds, etc. In the history of the Meath Hunt, which devoted space to notable horses and dogs, there is just one sentence devoted to female riders: 'Amongst the lady followers are Mrs Stern, Mrs Holford, Mrs Stewart, Mrs Watkin, Mrs Donnelly, Mrs John Dunville, Mrs G. Fowler, Mrs Hope-Johnstone, Miss Fitzgerald, Miss Dove, Mrs Sam. Watt, Mrs G. McVeigh. Miss Hone, and Mrs Steeds. ${ }^{40}$ Only four of the 26 hunts in Ireland mentioned any woman in their brief introductory histories. In the introduction to the Louth Hunt, a famous run from 1859 was recorded when only five members lasted to the end; four of these were named, the fifth was 'a lady'. ${ }^{41}$ The norm was to exclude women, and no women were mentioned at all in the introductions to the County Down Staghounds, County Galway Blazers, Westmeath, Kildare, Carlow, The island, Coollatin, Kings County, Queens County, Kilkenny, East Kilkenny, Wexford, Waterford, Tipperary, Templemore Staghounds, Limerick, Duhallow, Coshmore and Coshbride, United Hunt, South Union, Muskerry, or Carbery, though women were active members, and listed in the biographies throughout. The East Antrim Staghounds was one of the more egalitarian entries as men and women were listed together, rather than rattling off the female subscribers together at the end. ${ }^{42}$ The West Carbery hunt obviously recorded women in the introduction as it was necessary to document the improvements made by Edith Somerville during her term as Master of Hounds (1903-8). She had been hononary secretary since $1910 .{ }^{43}$

In the biographical section, women were rarely given their own biography, but rather were listed as part of a husband or father's biography. For example, after describing the exploits of Dunville, as daredevil master of hounds for Meath and as a hot-air balloon enthusiast (crossing the Irish channel in 1910; second in Gordon-Bennett Race, Berlin, 1908; English amateur record holder for long distance, having travelled 485 miles from London), his wife Violet was mentioned. It was simply stated that they had three children, her father's name, and

38 Brian Griffin, "The More Sport the Merrier, Say We": Sport in Ireland during the Great Famine'. Irish Economic and Social History 45, no. 1 (December 2018): 90-114, 101; B. Griffin, Cycling in Victorian Ireland (Dublin: History Press, 2006).

${ }^{39}$ Lady Castletown, [unpublished scrapbook], Doneraile Collection, National Library of Ireland, NLI/MS/3079.

${ }^{40}$ British Hunts and Huntsmen (vol. IV),302-308.

${ }^{41}$ Ibid., 340.

42 Ibid., 370.

${ }^{43}$ Ibid., 597. 
the fact that 'Mrs Dunville follows hounds regularly'. ${ }^{44}$ At the bottom of the same page, Mrs Alley, an 'American lady, who visits Ireland with her husband, and also hunts with the same hounds' was mentioned at the end of her husband's biography. Still, individuals were praised for their skill as 'lady riders'. In the East Kilkenny Hunt, Lady Kathleen Lindsey came from, and married into, hunting families and was 'acknowledged to be the cleverest Lady rider to hounds in her county.' She was continuing the family tradition, and it was reported that 'Her two little daughters have also been entered and promise to become expert horsewomen.' In neighbouring Tipperary, one of the 'most ardent lady followers of the Tipperary Hounds', Mrs Higgins, had 'hunted since her girlhood' in the 1870s. ${ }^{45}$ Other women were given the recognition of having their name in the margin, and were recorded independently. Hon. Mrs. R. Dewhurst's biography reads:

Until some three years ago, when she gave up hunting, there was no rider who went better to hounds than the Hon. Mrs Robert Dewhurst, the wife of Captain Robert Dewhurst, the wellknown trainer, of Clonsilla, county Dublin, and Newmarket, who follows the Meath and the packs of other countries. A contemporary writer said of Mrs Dewhurst:- 'She is dubbed the best Lady rider in the Meath country - if not in Ireland.' Always splendidly mounted, Mrs Dewhurst hunted in most of the countries in Ireland, and has also had a season with the Warwickshire. She lives principally at Greenmount, Clonsilla, county Dublin, spending some time each year at Newmarket. ${ }^{46}$

Marriage was not a barrier to participation in the hunt (this was true also for women's involvement in other sports such as tennis and cricket), nor was age. In the Kings County (Offaly) Hunt, Mrs Perry averaged twice a week, even though her husband could no longer hunt. Still, even though women were widely seen in the hunting field by 1900, with Edith Somerville having become Master of Hounds for West Carbery, and Mrs Kelly who was married to the Master in Louth, having become the whip, ${ }^{47}$ women were still perceived as lesser members of the hunt. The Sporting Life publication shows they were consistently presented as appendages to their hunting fathers and husbands.

\section{The freedom of the hunt}

A popular advice manual explained that 'Ladies do not attempt to hunt unless their skill as good horsewomen is beyond all question. Their husbands, their fathers, their brothers would not allow them to jeopardise their lives, unless their riding and experience, their courage, their nerve, and their instruction justified the attempt. ${ }^{48}$ The author was not exaggerating. There was a realistic possibility that anyone could get killed or seriously injured while hunting. Tom Hunt noticed a (recorded) death rate of about one hunter per decade in County Westmeath. ${ }^{49}$ The author Dorothea Conyers broke four bones, two toes and snapped her Achilles tendon in various accidents, meaning that she could never dance properly again, while her friend Mrs Crofton was killed while hunting in Kilkenny. ${ }^{50}$ In one Cork family, who were avid hunters and witnessed several serious hunting accidents, the mother, Esther Grehan, dislocated her shoulder in a fall far from home and had to limp to find help, while her daughter, who she had encouraged to hunt from a young age, "was thrown from her horse ... [and] remained

\footnotetext{
${ }^{44}$ Ibid., 312.

${ }^{45}$ Ibid., 522.

${ }^{46}$ Ibid., 318.

${ }^{47}$ Ibid., 345.

${ }^{48}$ Manners and Rules of Good Society: or solecisms to be avoided by a member of the aristocracy [33rd edition], 1911.

${ }^{49}$ It would appear that none of these were women. Hunt, Sport and Society, 18.

${ }^{50}$ Dorothea Conyers, Sporting Reminiscences (London: Metheuen, 1920). 51, 48.
} 
unconscious for 15 days' in $1915 .^{51}$ Newspapers reported the death and injury of various women while hunting. Interestingly, the pattern was not to blame the rider's lack of skill, as has been found in reports of female cycling accidents, but rather to present the event as an unavoidable and tragic accident. In 1877, Lady Inchiquin was thrown from her horse into a drain in 1877 because her horse 'slipped' ${ }^{52}$ When Millie Le Mottee was killed while hunting in 1924 as her horse chested a high narrow bank and fell on top of her, newspapers reported that she was 'an experienced horsewoman' who was 'riding a trained hunter'. ${ }^{53}$ The Cork Examiner described her as 'a great horsewoman, being a lightweight, and was an ardent follower of the U.H.C. [United Hunt Club] for the past twenty or thirty years. She was always to the fore in every good hunt.' ${ }^{54}$ Women could be genuinely admired for their hunting skill within the hunting fraternity. Lady Castletown's obituary in the conservative Irish Times led with the fact that she was 'a magnificent rider-one of the best of her day. There is a wall on the Buttevant road, celebrated as one of her most wonderful jumps - nearly six feet high; she jumped it backwards and forwards on a horse called Lambskin', while also emphasising her more feminine talents as 'a brilliant pianoforte player and a first-rate dancer ... [and] a wellknown hostess. ${ }^{55}$ For those women and girls who had the requisite skill, together with family support, hunting was a feasible outlet for physical activity.

\footnotetext{
${ }^{51}$ Stephen Grehan, diary entry, 30 March 1915 (Grehan Estate Collection, Boole Library Archive, University College Cork, IE/BL/EP/G/769).

52 'Hunting: Mr. Stackpoole's Harriers Accident To Lady Inchiquin', Irish Times, 5 December 1877, 6.

53 'Melancholy Hunting Accident: Young Lady Killed', Irish Times, 3 January 1924, 6.

54 'Details of the Fatality', Cork Examiner, 8 January 1924, 6.

55 'The Late Lady Castletown', Irish Times, 16 March 1927, 6.
} 


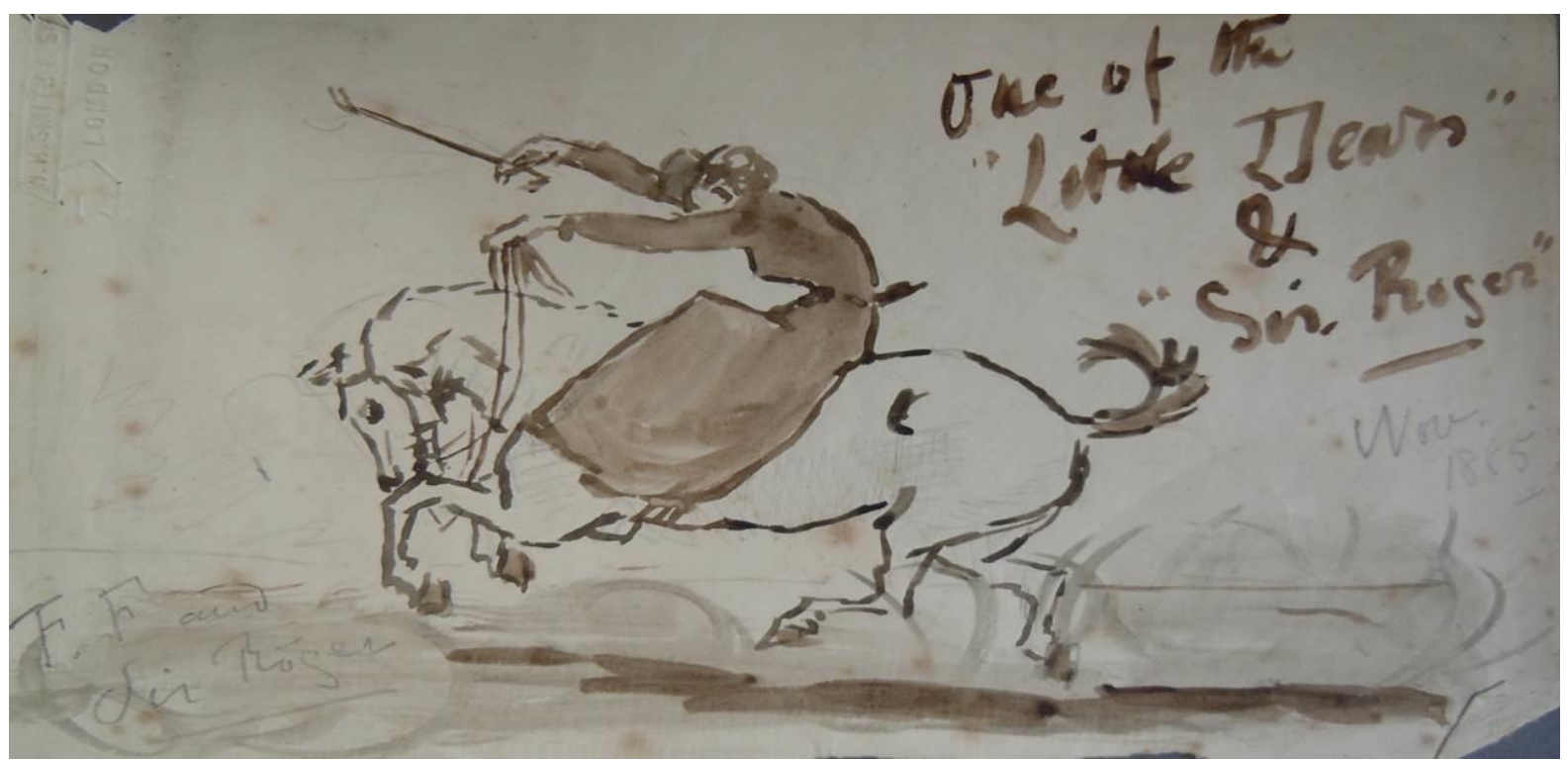

Sketch from Lady Castletown's scrapbook dated November 1885 depicting a woman riding 'Sir Roger' sidesaddle. The sketch demonstrates the skill and balance required to manage a horse while riding sidesaddle. Lady Castletown's scrapbook, Doneraile Estate Collection, National Library of Ireland, Ms. 3079.

Women's childhood experiences of the hunt were different from the mainstream advice manuals, which dictated how elite girls and teenagers should have their physical movement restricted and curtailed. Esther Grehan was eager for her daughters to develop the necessary skills, bravery and competitiveness to fully participate in the hunt. Even on her first hunt, Esther's daughter, May, was encouraged to exhibit bravery by her parents:

[S]he had several jumps[;] the pony pulled her sometimes \& she was frightened particularly when she saw Lady Listowel fall at a fence - However Stephen cheered her on \& she jumped it alright. ${ }^{56}$

The author, Dorothea Conyers (née Blood-Smith) was born into a committed hunting family in Fedamore, county Limerick. ${ }^{57}$ Conyers first remembered being lifted onto a horse at the age of three. Her father, a landlord and Colonel, died during her early childhood, and she credited her mother for her early training in horsemanship. Her mother (Amelia née Spaight of Derry Castle, County Tipperary, d.1912) was an exceedingly able and fearless horsewoman who could ride 'anything'. During her widowhood and Dorothea's youth, Amelia spent her time training 'wild two and three year olds which tied themselves into knots as they bucked'; a task made much more difficult by the custom of riding side-saddle. ${ }^{58}$ Amelia was one of only two women who hunted in her native County Limerick before her marriage in $1860 .{ }^{59}$ Amelia first taught her daughter to ride bareback while sitting sideways on the horse, or side-saddle without a saddle, which must have led to the development of excellent balance and competence on the horse. Dorothea graduated to a second-hand side-saddle and cut down riding habit of her own at the age of eight. Both side-saddles and habits were extremely expensive, so it was understandable that her mother might wait until Dorothea, and her mount, were a little bigger before investing in either. By the time Dorothea had reached adulthood, women were more commonly found in the field. Dorothea continued to ride to hounds throughout her adult life; a passion which she funded partly through her prolific writing career. In her 1923 memoir,

\footnotetext{
${ }^{56}$ Esther Grehan, diary entry, 30 November 1895 (Grehan Estate Collection, Boole Library Archive, University College Cork, IE/BL/EP/G/840).

${ }^{57}$ Frances Clarke, 'Conyers, (Minnie) Dorothea Spaight Blood-Smith', in Dictionary of Irish Biography ed. James McGuire and James Quinn (Cambridge University Press, 2009).

${ }^{58}$ Conyers, Sporting Reminisences, 2.

59 Ibid.
} 
Sporting Reminiscences, Conyers professed that if her publishers would allow, the book would consist of two chapters 'Foxhunting with all the honours' and 'a toast - Foxhunting' ${ }^{60}$ In fact, there is little else in the work. Sporting Reminiscences successfully conveys how deeply-rooted the obsession with foxhunting and horses lay in some families.

Conyers' 1904 novel The Boy, Some Horses, and a Girl provided, for an English readership, a detailed description of hunting, and the freedom of interaction between the sexes, in county Limerick. ${ }^{61}$ The novel was replete with negative Irish stereotypes. ${ }^{62}$ The premise of the novel is that three English men-Travers, Kane-Norton, and the much younger twentyfive-year-old 'Boy' Norman Rivers - spend a hunting season in the fictional Cahirvally, and there fall in love with the hunting sport available in Ireland. The men make efforts to marry wealthy Irish hunting women, in an effort to facilitate their remaining in Cahirvally to hunt for the rest of their lives. The most desirable woman, the 'girl' of the title, is Sheila Maguire, an unmarried heiress and the owner of Dunmore, a house 'right in the centre for hunting' ${ }^{63}$ The three men form a friendship with Sheila Maguire on the hunting field, and she invites them for a day's shooting on her estate. ${ }^{64}$ Eventually she proposes to the boy, who has no fortune of his own, based on her understanding that he is the only suitor who is in love with her, rather than wishing to marry her purely as a passport to hunting in Cahirvally. A woman proposing to a man subverted the gendered expectations of the time. However, Conyers reassured her readers that he accepted her proposal 'in a way which showed that, if he were to be man, he also meant to be master' ${ }^{65}$

As a woman who was an active hunter herself, Conyers stressed the physical bravery of her female characters, while also presenting them as being desirably feminine. The female characters were so knowledgeable about horses and hunting that they could both guide the newcomers over the terrain, and trick them into buying sub-standard horses. In an early meeting, Sheila Maguire mocks Norman Rivers for the pity he feels for fox cubs on his first day out cubbing (where fox cubs rather than adult foxes are hunted), but she is also experienced enough in judging horses and riders to be able to tell that he had the 'makings of a sportsman'. ${ }^{66}$ Sheila Maguire is portrayed as much more experienced than Rivers: he only started hunting the previous year; she has hunted all her life, even though both of her parents were killed by a runaway horse. ${ }^{67}$ Later in the book, Maguire saves Rivers' life due to her far superior knowledge of horses. Rivers is riding a notoriously bad-tempered mare, and is unable to keep the horse under control as she bolts over fences, ditches and banks in a point-to-point race. Maguire, with her superior knowledge, is able to cut across the field on her horse. She stops Rivers from falling down a ravine. ${ }^{68}$

On another occasion, Conyers has the Kane-Norton character guided over fences by 'a small girl with a brilliant complexion and pathetic blue eyes'. ${ }^{69}$ The Englishman notes that despite her 'badly-fitting habit, she rode perfectly'. As she shows him where to jump, he admires 'the perfect way in which she handled the roan'. The young female rider seeks out challenges, and 'whenever [Kane-Norton sees] a gap his guide had some excellent reason for

\footnotetext{
${ }^{60}$ Conyers, Sporting Reminiscences, 1.

${ }^{61}$ D. Conyers, The Boy, Some Horses, and a Girl: The Tale of an Irish Trip (London: E. Arnold, 1905; reptd. General Books, 2009).

${ }^{62}$ Ibid., $51-55$ (e.g.).

${ }^{63}$ Ibid., 39.

${ }^{64}$ Ibid., 39.

${ }^{65}$ Ibid., 106.

${ }^{66}$ Ibid., $21 ; 39$.

${ }^{67}$ Ibid., 2.

${ }^{68}$ Ibid., 98 .

${ }^{69}$ Ibid., 40.
} 
not going that way', and so they jump 'a wide stream, a built wall, and a big double'. Over the course of a single chase, the woman manages to dupe Kane-Norton into buying her horse without passing the vet's examination through a combination of superior skill and femininity; she finally meets his eyes with a 'glance of pure pathos, so perfect as to give a hint of practice' ${ }^{70}$ It is later revealed to him that the female rider, an 'innocent little monkey', was 'one of the biggest horse-copers in the country, and has forgotten more about a horse than you ever knew. ${ }^{71}$ Irish women are shown to be just as capable as Irish men in duping their lesssavvy English visitors. The narrator emphasises the easy way in which relationships might be struck up between men and women in the hunt, observing that this unnamed female character took the occasion 'as a friendly introduction, and used her blue eyes upon Kane-Norton every time she met him'. ${ }^{72}$ By the end of the novel, it is implied that he will soon propose to her. ${ }^{73}$

Another family of fictional sisters, the four Miss Clancys, display extreme competitiveness (a perceived masculine characteristic) and are observed to

belong to the race of sportswomen who rode hard and straight, but who looked on hounds as necessary aids to pleasure, and who marked the joys of their gallops by their relevant position to other habits. Moreover, if a man fell, it was not unlikely that the eldest Miss Clancy would jump on him. ${ }^{74}$

This thrill at riding hard across country was enjoyed even by the youngest 'screwed into her mother's old saddle, on the patient half-clipped cart pony'. ${ }^{75}$ However, these women were also capable of expressing feminine desire and hoped to secure husbands, and preferably English ones, on the hunting field. ${ }^{76} \mathrm{~A}$ similar view of the hunt as a space for women to independently meet future partners, particularly British military partners, was jokingly referred to by the nonfictional Lady Castletown in a poem pasted into her scrapbook, which encouraged the unmarried women of Kildare to 'see the way to promotion on every side', as there were soldiers from numerous barracks riding with the hunt. ${ }^{77}$ Another poem, entitled 'A Foggy Flirtation', dated 22 January 1889, describes a more illicit relationship between 'a youth and a matron suspiciously placed [...] with his arm encircling the motherly waist'. ${ }^{78}$ A third poem, written in the first person, describes an unmarried couple who managed to be cut off from the rest of the field, and walked home together through the twilight where the male partner could admire the "with the motion of the saddle, as it rose and as it fell, I see her dainty patent leather boot ... I watched her figure gently sway from side to side'. ${ }^{79}$ In her own memoir, Dorothea Conyers reported that 'girls had to have a chaperon[e] then even hunting' during her early years. The County Limerick chaperone, Mrs Wyndham Gabbett, who rode with Conyers and her friends, appears to have been primarily interested in the sport, rather than control of the young female hunters. ${ }^{80}$ This level of freedom, to interact with men who had not necessarily been introduced to the young woman or vetted by her family, was quite unique given the limited opportunities women had to interact with men outside the pattern of controlled freedom, which operated through a series of invite-only events which girls regularly attended during their marriageable years.

\footnotetext{
${ }^{70}$ Ibid., 40.

71 Ibid., 41.

72 Ibid., 41.

${ }^{73}$ Ibid., 110.

${ }^{74}$ Ibid., 89.

75 Ibid., 89.

76 Ibid., 69.

77 'Kupenball', [n.d.], Lady Castletown's Scrapbook, NLI/MS/3079.

78 A foggy flirtation', 22 January 1889, Lady Castletown's Scrapbook, NLI/MS/3079.

79 'The Pathetic Ballad of the Patent Leather Boot', Lady Castletown's Scrapbook, NLI/MS/3079.

${ }^{80}$ Conyers, Sporting Reminiscences, 32.
} 


\section{Esther Grehan}

Hunting was a pastime which involved stamina and strength, but it was also something which was available to those who were not 'athletes' in the strictest sporting sense. Participants ranged widely in terms of age, health and physique. Esther Grehan (b.1860, m. 1883, d. 1900) was the wife of a landlord who lived just outside the town of Banteer in North Cork. She had been born into the Chichester family in Roscommon. Both her natal and her marital family were deeply invested in the sport, and this interest spanned both male and female members. Esther's marital family home, Banteer, was the ideal base for hunting. The North-West County Cork area was covered by the Duhallow Hunt, who held meets at least every Tuesday and Saturday during the winter season. If the couple could not ride to the meet, they lived only a couple of miles from a train station which allowed them to take advantage of hunting across North Cork from Charleville down to Blarney. Esther Grehan, her husband, her aunts, and her daughters all hunted as much as possible. I wish to focus on Esther Grehan to further demonstrate that the hunting field allowed an opportunity for women to act independently, despite the wider restrictions on their behaviour reflective of the patriarchal nature of their society. Hunting, and being on horseback was never a risk-free activity. On one occasion, for example, Esther Grehan recorded that 'a woman who was trotting on the road', and thus avoiding the more dangerous gallop over stone walls and hedges, 'fell when her horse crossed its legs, she must have gone head first as was concussed for quarter hour'. ${ }^{81}$ Grehan was well aware of this, but when recording the falls of herself or others, there was never an implication that the risk outweighed the benefit, or the pleasure of the activity.

Esther Grehan had married in 1883 at the age of twenty-three. She and her husband Stephen had a companionate marriage, and their diaries reveal that they actively enjoyed spending time in each other's company and continued to share the same bed throughout their marriage. Her interest in hunting was clear from the start and facilitated by her husband. She even asked for a hunting horse as a wedding gift from her husband, though she was also very happy to accept the gift of lace, which was a fabric only appropriate for 'married ladies' to wear and would give her 'a certain cachet of matronliness' ${ }^{82}$ For Esther Grehan, as for many other women of her class, marriage was a step into independence and social status-despite the legal restrictions on women at the time. In marriage, women gained the right to manage their own household and staff of servants. Esther Grehan actively exercised this power and could be swift to terminate her servants' employment if she was not happy with them. The Grehans had six children, four girls and two boys, the elder of whom died in infancy of an apparent cot death or Sudden Infant Death Syndrome. Esther Grehan was challenged by several health issues. Within the first year of her marriage, it was necessary for her to seek treatment for her lungs. She was treated for asthma and bronchitis at various times, and had her nose cauterised. ${ }^{83}$ It may be that she had contracted tuberculosis. In 1885 and 1898, Grehans spent time in the famous spa town of Davos in Switzerland, where those who could afford it went to try to cure the disease, which was often a death sentence during the nineteenth-century. ${ }^{84}$ The treatment Grehan underwent was severe. In one letter home she reported that the skin was burned off her chest 'which is what the doctor wants for probably the next three months he says till that lung gets sound'. ${ }^{85}$ Grehan also suffered from gynaecological problems, particularly after the birth of her last child in 1895, when the placenta was not properly

\footnotetext{
${ }^{81}$ Esther Grehan, diary entry, 1 December 1894 (Grehan Estate Collection G/839).

${ }^{82}$ Esther Chichester to Stephen Grehan, 30 November [1882] (Grehan Estate Collection G/689).

${ }^{83}$ Esther Grehan, diary entry, 13 March 1897 (Grehan Estate Collection G/842).

${ }^{84}$ Esther Chichester to Stephen Grehan, 27 November 1885 (Grehan Estate Collection G/702); Esther Grehan, diary 1898 (Grehan Estate Collection G/843).

${ }^{85}$ Esther Grehan to Stephen Grehan, 25 November 1885 (Grehan Estate Collection G/751; G/792).
} 
dispelled, and she went through months of debilitating bleeding and ultimately painful treatment in Dublin. ${ }^{86}$ Her illnesses culminated in 1897, when she collapsed and was left unconscious for two weeks. She became dangerously ill in September 1897 after travelling home from France via Southampton and Plymouth and collapsed at her home. Her family and medical practitioners were worried enough to arrange for extreme unction and to resort to shaving her hair and blistering her head. ${ }^{87}$ Her final attempt at a cure took place in 1900 when she and her husband took a cruise through the Mediterranean, and ultimately to Sri Lanka where she died and is buried ${ }^{88}$ It was hoped that the air there would be good for lungs, though in a letter to her sister, Grehan revealed that she did not think this journey could do her any good, but that it was good for her husband to feel that he was doing something to help her.

Such a woman, who died at the age of forty, and who once wrote to her sister, 'I rested after about 11 on the sofa doing nothing till lunch- I feel humbug, I look so well and fat- but if I have any thing to do I collapse helplessly ${ }^{69}$ could hardly be described as an ideal athlete. And yet, hunting was an important and integral part of her life. Ten years into her marriage, she had a new habit made for hunting for the 1894 hunting season, as her interest in the sport increased rather than decreased with time. ${ }^{90}$ Her interest in the hunt was not just something to be engaged in on the day. As her marriage progressed, she also engaged in training and schooling horses for the hunt. Her horse Goblin took some work. In April 1894 he nearly bucked her off, and on the first day of hunting that autumn he was 'heavy' in her hands. By January he was still causing problems. She reported; 'I nearly took two tosses one the Goblin fell on his nose in a field \& after 3 attempts recovered himself $\&$ next at a fence. ${ }^{, 91}$

Grehan kept a brief diary throughout her married life. It rarely went beyond recording her health issues and the comings and goings of her husband and children. She became passionate when she was describing a hunt meeting, her writing became cramped as she sought to squeeze in the entire record of the chase into the day's space. She recorded where they met, if and where they found the fox, the length of the chase, how her and her husband's horses behaved, as well as any dramatic events like a bad fall to herself or another rider. On one occasion she recorded that 'Willie Barry had a nasty fall on his head \& the horse kicked him on the back of the head', he was unconscious for twenty-four hours. ${ }^{92}$ She also reported disappointedly when she 'had to give up all idea of hunting' the following day when she was particularly unwell. ${ }^{93}$ On days when she could not hunt, she lived through the experiences of her family. She wrote of her husband and twelve-year-old daughter 'they had a real good hunt $\&$ very fast ... Magda rode the whole [distance] of course it was too fast for the pony. She rode beautifully'. ${ }^{94}$ For Grehan, the hunt was not just a pastime, but also an expression of her sense of self and her vitality. Her satisfaction was palpable when she could record, for example, that she was 'delighted to find I was not tired riding home in the teeth of the wind \& rain' from a meet at Ballygiblin, a distance of about 33 kilometres. ${ }^{95}$

\footnotetext{
${ }^{86}$ Esther Grehan, diary, 13 April 1896 (Grehan Estate Collection G/841). See also in the same diary: entries 3, 14, 16 February and 4 April for examples of debilitating impact on her health, and Esther Grehan, diary, 2, 20 , 25 April; 1, 16, 21, 27 May 1896. See Grehan Estate Collection G/841 for details of treatment.

${ }^{87}$ Esther Grehan, diary, 21, 22 September 1897 (Grehan Estate Collection G/842).

${ }^{88}$ Stephen Grehan to Amy Chichester, 3 May 1900 (Grehan Estate Collection G/835).

${ }^{89}$ Esther Grehan to Amy Chichester, 11 November 1899 (Grehan Estate Collection G/830).

${ }^{90}$ Esther Grehan, diary entry, 2 November 1894.

${ }^{91}$ Esther Grehan, diary entry, 4 April 1894; 29 October 1894; 17 January 1895.

92 Esther Grehan, diary entry, 22 December 1894.

${ }^{93}$ Esther Grehan, diary entry, 29 January 1897.

${ }^{94}$ Esther Grehan, diary entry, 30 January 1897.

${ }^{95}$ Esther Grehan, diary entry, 2 March 1897.
} 
Esther Grehan managed her own relationship with hunting, based on her own knowledge of her body and health. On some days she might record that her muscles were tired after stretching herself to an all-out seven mile chase of a fox, ${ }^{96}$ or a hard gallop over 'some big stone gaps ${ }^{97}$ while on another day she might ride to the meet or drive in the dog cart and watch the chase from the road. ${ }^{98}$ Her interest in the hunt was supported by her doctor, who was also involved in the Duhallow Hunt. In February 1895, after suffering a nervous attack which she put down to having to 'lie back suddenly' while jumping under a tree, and being prescribed the sedative bromide, she was happy to report that the doctor said that she could hunt the following day, provided that she did not 'fatigue' herself. ${ }^{99}$ The hunt was an arena where Grehan could cease to be a weak woman beset by health problems and could be an independent member of the hunt, engaging in a sport which she loved; a sport which demanded skill, balance and strength. The article reporting her death in the Cork Examiner referred to her 'indifferent health' but described her as 'an ardent lover of the chase' while also mentioning her 'many amiable and sympathetic qualities, she being above all a thorough lady'. ${ }^{100}$

\section{Conclusion}

The passion which Dorothea Conyers, Esther Grehan, and many others felt for hunting was understandable when placed against the society in which they lived. While elite women's lives were in no way as curtailed as advice literature and received wisdom would suggest, sport, and hunting in particular, was an important physical outlet. Women from hunting families had the benefit of physical independence and the opportunity to dominate both beast and landscape when they went hunting. As Munckwitz has argued

On horseback women could literally ride over boundaries and into new spaces that they could not have entered or explored otherwise. The new space of the hunting field enabled female riders to develop personal autonomy as well as the formerly masculine qualities of assertion and authority. Here they reinvented the traditional feminine ideal in a new space. ${ }^{101}$

While there were some who criticised women who hunted, women could generally hunt without losing access to their perceived femininity. Indeed, the author of Manners and Rules, a successful etiquette manual, believed that 'there is no arena better fitted to display good riding on the part of women than the hunting field, and no better opportunity for the practice of this delightful accomplishment and for its thorough enjoyment. ${ }^{102}$ The dangerous sport of hunting which existed with the aim of brutally tearing an exhausted fox to shreds was listed as an 'accomplishment'; something women might master in order to make themselves appear more attractive and more feminine. This accomplishment was open to women of all ages and levels of physical strength; provided that they had the benefit of class background, family support and the requisite skill to master the horse.

Note:

Archival Materials referenced in this article include the Grehan Estate Collection (IE/BL/EP/G, Boole Library Archive, University College Cork) and the Doneraile Estate Collection (NLI/MS/3079ff, National Library of Ireland).

\footnotetext{
${ }^{96}$ Esther Grehan, diary entry, 14 February 1894.

${ }^{97}$ Esther Grehan, diary entry, 21 February 1894.

${ }^{98}$ Esther Grehan, diary entry, 8 March 1894.

${ }^{99}$ Esther Grehan, diary entry, 3-4 February 1895, Grehan Estate Collection.

100 'Death of Mrs Grehan of Clonmeen, Banteer', Cork Examiner, 17 April 1900, 3.

${ }^{101}$ Munkwitz, 'Angels', 520-521.

102 Manners and Rules, 220.
} 


\section{Bibliography}

Bence-Jones, M. Twilight of the Ascendancy. London: Constable, 1987.

British Hunts and Huntsmen ... England (North), Scotland, and Ireland: Compiled in Conjunction with The Sporting Life. Vol. IV. London: Biographical Press, 1911.

Canavan, T. "“Erin cordially welcomes the Empress': Elizabeth of Austria-Hungary in Ireland, 1879 and 1880", History Ireland 19, no. 3 (2011): 30-33.

Carbery, M. Happy World: Story of a Victorian Childhood. London: Longmans, Green \& Co., 1941.

Conyers, D. Sporting Reminiscences. London: Metheun, 1920.

. The Boy, Some Horses, and a Girl: The Tale of an Irish Trip. London: E. Arnold, 1905. Reptd. General Books [generalbooks.net], 2009.

Cork Examiner [newspaper].

“Death of Mrs Grehan of Clonmeen, Banteer", Cork Examiner, 17 April 1900, 3.

"Details of the Fatality", Cork Examiner, 8 January 1924, 6.

Curtis, L.P., Jr. "Stopping the hunt, 1881-1882: an aspect of the Irish Land War" in Nationalism and Popular Protest in Ireland ed. C.H.E. Philpin ([1987] Cambridge University Press, 2002), 349-402.

Dooley, T., Decline of the Big House in Ireland: a Study of Irish Landed Families, 18601960. Dublin, 2001.

Drucker, N. "Hunting and shooting - leisure, social networking and social complications: microhistorical perspectives on colonial structures and individual practices - the Grehan family, Clonmeen House, Ireland" in Was Ireland a Colony? Economy, Politics, Ideology and Culture in Nineteenth-century Ireland ed. T. McDonough (Dublin: Irish Academic Press, 2005), 117-44.

Griffin, B. Cycling in Victorian Ireland. Dublin: History Press, 2006.

"“The More Sport the Merrier, Say We': Sport in Ireland during the Great Famine". Irish Economic and Social History 45, no. 1 (December 2018): 90-114.

"The Big House at Play: Archery as an Elite Pursuit from the 1830s to the 1870s" in Irish Elites in the Nineteenth Century ed. Ciaran O’Neill. Dublin: Four Courts, 2013.

Hinkson, P., ed. Seventy Years Young: Memories of Elizabeth, Countess of Fingall. London: Collins, 1937. Reptd. Dublin: Lilliput Press, 1992.

Hunt, Tom. "Women and Sport in Victorian Westmeath". Irish Economic and Social History 34 (2007): 29-46.

Sport and Society in Victorian Ireland: the Case of Westmeath. Cork University Press, 2007.

Irish Times [newspaper]

'Hunting: Mr. Stackpoole's Harriers Accident To Lady Inchiquin'. Irish Times, 5

December 1877, 6.

'Melancholy Hunting Accident: Young Lady Killed'. Irish Times, 3 January 1924, 6.

'The Late Lady Castletown', Irish Times, 16 March 1927, 6. 
Jungnickel, K. “'One needs to be very brave to stand all that': Cycling, Rational Dress and the Struggle for Citizenship in Late Nineteenth Century Britain”. Geoforum 64 (2015) 362-371.

Lewis, G. Edith Somerville: a Biography. Dublin: Four Courts Press, 2005.

Liston, Katie. "Sport and Leisure”. The Sociological Review 59, no. 1_suppl (June 2011): $160-80$.

Manners and Rules of Good Society: or solecisms to be avoided by a member of the aristocracy [33rd edition]. 1911.

Munkwitz, Erica. "Angels and Amazons: Fox-hunting and Sporting Emancipation for Women”, The International Journal of the History of Sport 35, no. 6 (2018) 511-529.

Ó hÓgartaigh, M. Quiet Revolutionaries: Irish Women in Education, Medicine and Sport, 1860-1964. THP Ireland, 2011.

Rouse, P. "The Sporting World and the Human Heart: Ireland, 1880-1930”. Irish Studies Review, 27, no. 3 (2019), 309-324.

Vickery, A. "Golden Age to Separate Spheres? A review of the categories and chronology of English women's history”. Historical Journal 36, no. 2 (1993): 383-414. 